
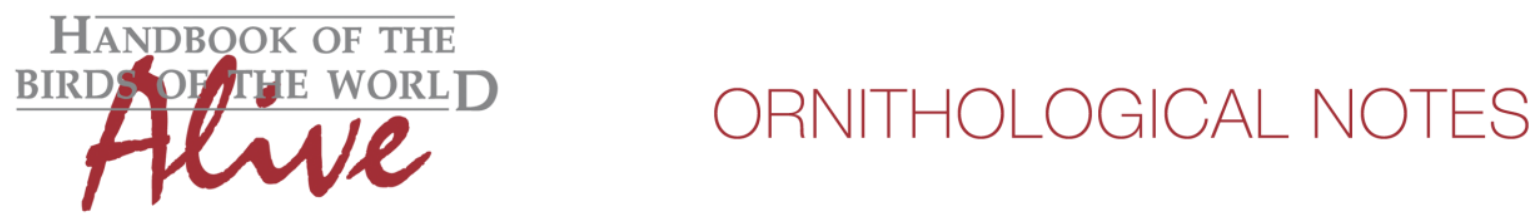

\title{
Notes on the vocalizations of Yellow-tufted Dacnis (Dacnis egregia)
}

Peter Boesman

In the following we briefly analyze and compare voice of Yellow-tufted Dacnis (Dacnis egregia) with Black-faced Dacnis (Dacnis lineata). We also try to quantify the extent of any vocal differences using the criteria proposed by Tobias et al. (2010), as a support for taxonomic review. We have made use of sound recordings available on-line from Xeno Canto $(X C)$.

Few recordings are available of both species as these seem to vocalize rarely other than uttering some rather insignificant call notes. An overview, illustrated with sonograms:

\section{D. egregia}

The call, a short "tsrip" is actually a high-pitched short rattle consisting of 3-5 notes (thin vertical lines close together on sonogram). Most of the energy is in the range $8-10 \mathrm{kHz}$ (occasionally slightly lower).

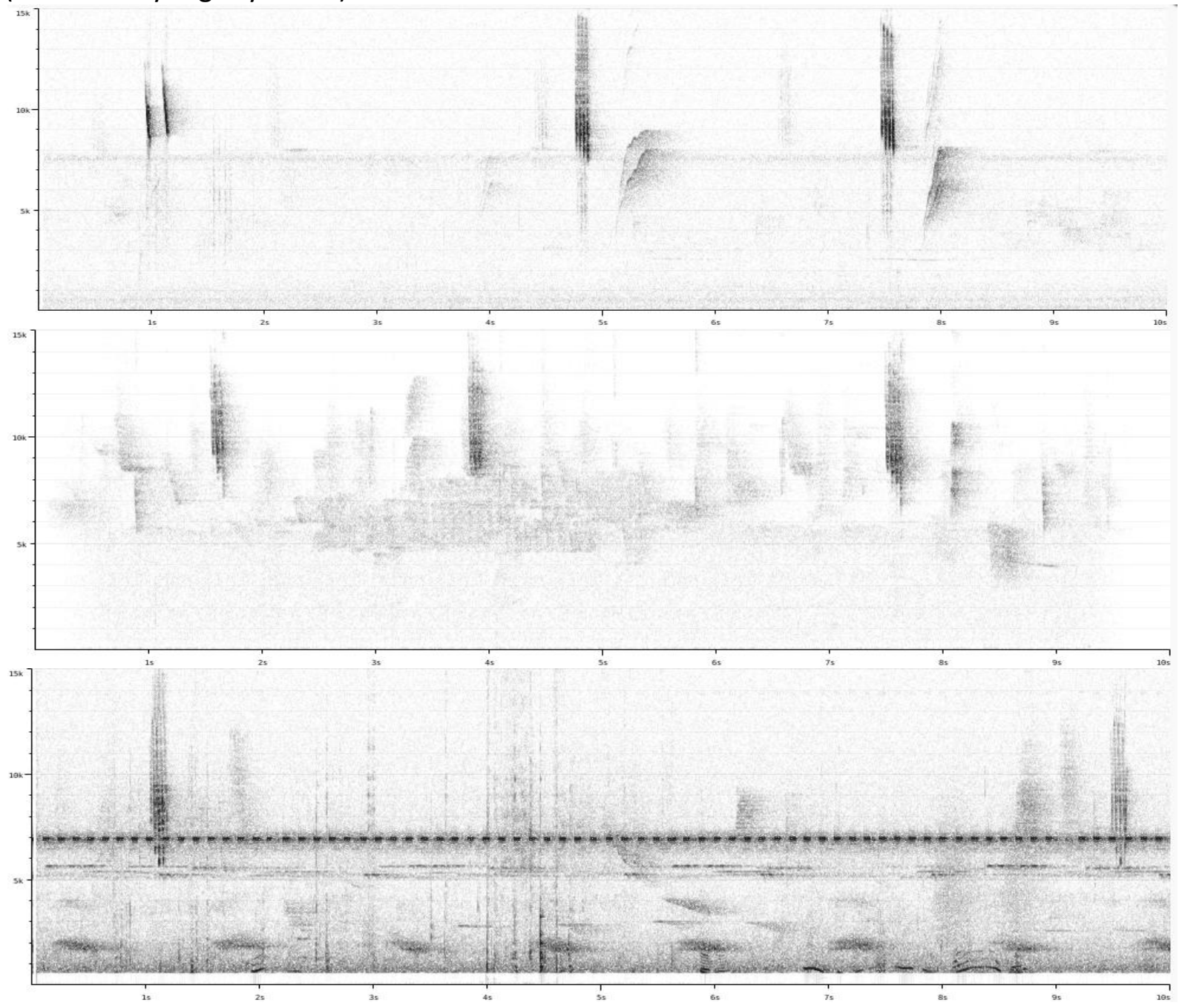




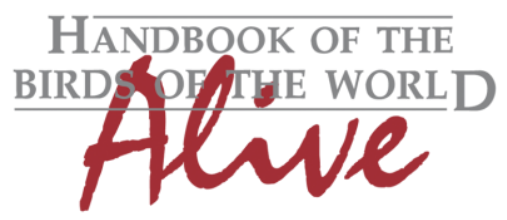

\section{ORNITHOLOGICAL NOTES}

\section{D. lineata}

Call "tsrip" is actually a high-pitched short rattle consisting of 3-6 notes (thin vertical lines close together on sonogram). Most of the energy is in the range $8-10 \mathrm{kHz}$ (occasionally slightly lower)

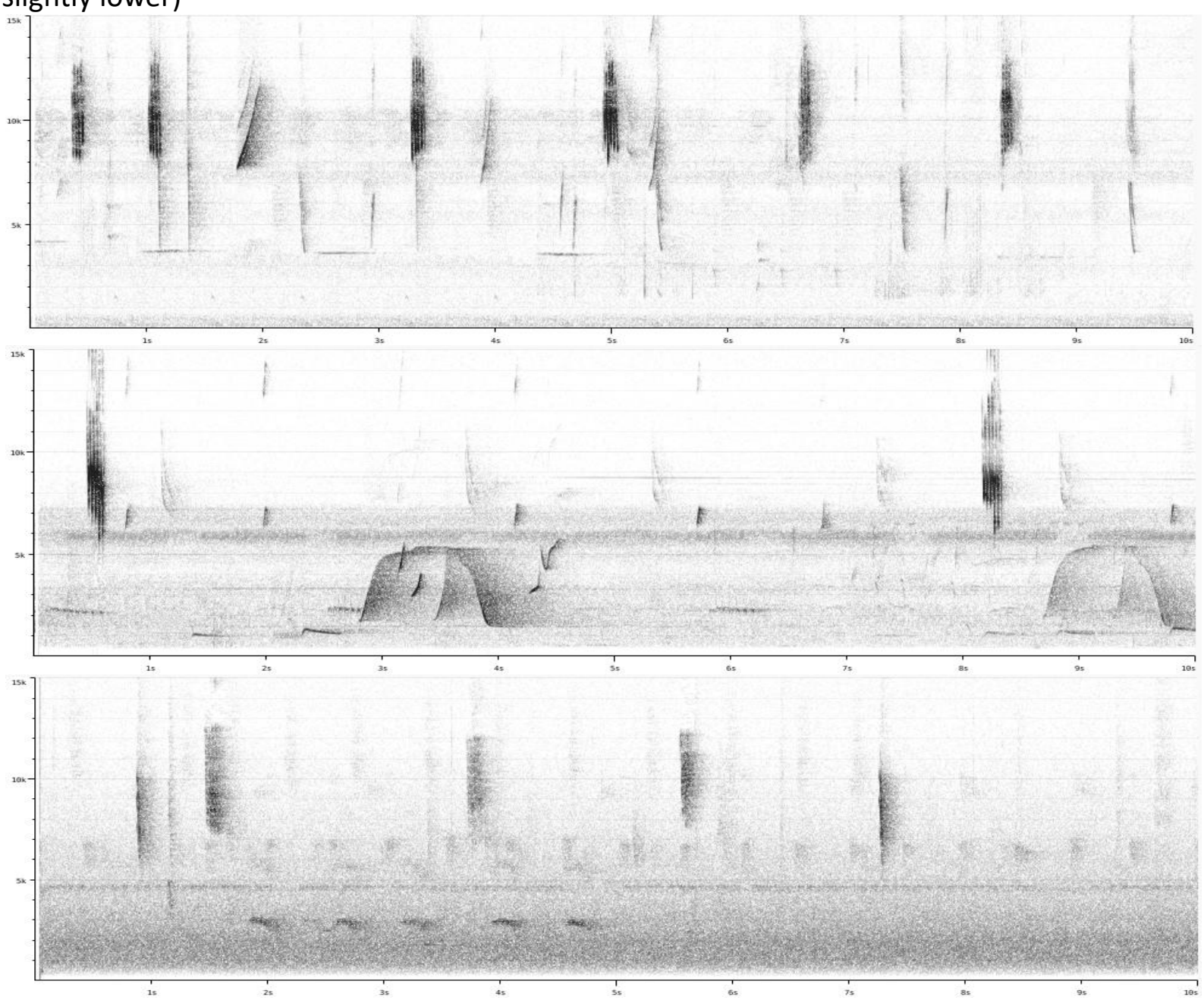

From the above, it is clear that the main call note is about identical. Recordings of song would be needed to find out if there is any vocal difference.

This note was finalized on 19th October 2016, using sound recordings available on-line at that moment. We would like to thank in particular the sound recordists who placed their recordings for this species on XC: Tayler Brooks, Fernando Igor de Godoy, Olaf Jahn, Dan Lane, Gabriel Leite, Andrew Spencer and Mark Todd.

\section{References}

Tobias, J.A., Seddon, N., Spottiswoode, C.N., Pilgrim, J.D., Fishpool, L.D.C. \& Collar, N.J. (2010). Quantitative criteria for species delimitation. Ibis 152(4): 724-746. 


\section{Recommended citation}

Boesman, P. (2016). Notes on the vocalizations of Yellow-tufted Dacnis (Dacnis egregia). HBW Alive Ornithological Note 439. In: Handbook of the Birds of the World Alive. Lynx Edicions, Barcelona. (retrieved from http://www.hbw.com/node/1287369 on 9 December 2016). 